\title{
HUBUNGAN PERILAKU MENCUCI DENGAN KONTAMINASI TELUR NEMATODA USUS PADA SAYURAN KUBIS (Brassica oleracea) PEDAGANG PECEL LELE DI KELURAHAN WARUNGBOTO KOTA YOGYAKARTA
}

\author{
Dyah Suryani, S.Si, M.Kes \\ Fakultas Kesehatan Masyarakat, Universitas Ahmad Dahlan Yogyakarta
}

\begin{abstract}
Background: Vegetables can be eaten whole or in part in fresh or raw (fresh vegetables) or cooked. Vegetables is beneficial for health because they contain relatively high nutritional vitamins and minerals, one of which is cabbage or cabbage. Cabbage has dicucipun may still contain pests and diseases, such as nematodes. Due to poor washing. In Indonesia, the nematode intestine is still a public health problem is Ascaris lumbricoides, hookworm and Trichuris trichiura. Soil, vegetables and water is an important transmission media, a growing number of eggs found in the sources of contamination (vegetable, soil, etc.) will be accompanied by an increase in the degree of endemics. Advanced Research goal is to look at the relationship between the behavior of washing vegetables with intestinal nematode egg contamination in vegetable cabbage merchant in the Village of catfish pecel Warungboto city of Yogyakarta. This study has the benefit of policy - making in disease eradication wormy and add information that is consumed raw vegetables can infect humans through the intestinal nematode egss Atlanta.

Methods: The study was observational analytic study with cross sectional research design. Washing behavior obtained by direct observation to guide traders with check list. Vegetable sprouts are used as raw vegetables (vegetables) contained on the merchant pecel Warungboto catfish in the Village of Yogyakarta. Wash solution for the deposition of intestinal nematode eggs used was $0.2 \% \mathrm{NaOH}$ solution. Examination conducted by using techniques of direct examination and then examined under a microscope. Data examination of the behavior of the cabbage and wash vegetables presence or absence of intestinal nematode eggs, species of intestinal nematode eggs. Data were analyzed using univariate and bivariate analysis with chi square analysis.
\end{abstract}

Examination results: The results of this examination showed that of 26 respondents found 16 respondents $(61.5 \%)$ had not properly washing vegetables and 10 respondents $(38.5 \%)$ had a good washing vegetables. Bivariate analysis for the behavioral relationship with the intestinal nematode egg contamination in vegetable cabbage is a value sig $=0.35$ is greater than the value of alpha $(\alpha=0.05)$ and $\mathrm{RP}=3.125(95 \% \mathrm{Cl}: 0.424$ to 23.007$)$.

Conclusion: There were no relationship between the behavior of washing vegetables with egg contamination in vegetable cabbage worms in the shop pecel catfish Yogyakarta Village Warungboto 2011.

Keywords: Behavior, vegetables cabbage (Brassica oleracea), intestinal nematode eggs.

\section{PENDAHULUAN}

Manusia memerlukan konsumsi zat-zat gizi untuk menciptakan tubuh yang sehat. Zat-zat gizi tersebut antara lain kalori, karbohidrat, lemak, protein, vitamin dan mineral yang berfungsi untuk pertumbuhan dan kesehatan tubuh. Zat-zat gizi tersebut tidak diperoleh dari satu macam bahan makanan saja melainkan dari beberapa bahan makanan yang berupa makanan pokok, lauk pauk, buah, susu maupun sayuran. Sayuran merupakan makanan pendamping makanan pokok yang kaya gizi. Di dalam sayuran terkandung protein, vitamin dan mineral. Sayuran dalam bidang hortikultura dapat diartikan bagian dari tunas, daun, buah dan akar 
tanaman yang lunak dan dapat dimakan secara utuh atau sebagian dalam keadaan segar atau mentah (lalapan) atau dimasak, sebagai pelengkap pada makanan berpati dan daging. ${ }^{1}$

Lalapan bermanfaat untuk kesehatan karena mengandung zat gizi relatif tinggi yang sangat dibutuhkan tubuh, yaitu vitamin dan mineral. Hampir semua jenis vitamin dan mikronutrien (terutama mineral) yang penting bagi tubuh terdapat di dalam lalapan. Vitamin dan mineral penting berguna untuk menjaga metabolisme tubuh. Selain vitamin dan mineral, lalapan memiliki kandungan serat yang tinggi Sayuran yang sering digunakan menjadi lalapan di warung makan lesehan, meliputi timun, kemangi, kacang panjang, kubis atau kol dan tomat. ${ }^{2}$

Kol memang mudah ditemukan baik di pasar tradisional maupun supermarket. Dibanding sayuran jenis lain, kol harganya tergolong murah. Dengan demikian, kol cocok menjadi alternatif pilihan dalam menyiasati melambungnya harga sayuran lain. Kubis banyak mengandung vitamin dan mineral yang sangat dibutuhkan tubuh manusia. Sebagai sayuran, kubis dapat membantu pencernaan, menetralkan zatzat asam dan memperlancar buang air besar. ${ }^{3}$ Kubis atau kol dikonsumsi sebagai sayuran daun, diantaranya sebagai lalab (lalap) mentah dan masak, lodeh, campuran bakmi, lotek, pecal, asinan dan aneka makanan lainnya. ${ }^{4}$

Kubis yang dicuci bersih kemungkinan besar masih mengandung hama penyakit. Hama kubis banyak jenisnya. Kalau dikelompokkan, hama dari bangsa serangga yang paling banyak. Hama lain bangsa moluska dan bangsa nematoda. ${ }^{3}$ Penggunaan sayuran mentah yang langsung dikonsumsi dimungkinkan masih terdapat pencemaran dari bibit penyakit. Tercemarnya sayuran adalah karena kebiasaan dan cara hidup yang kurang higienis. Penyebaran cacing usus pada makanan sayuran dapat terjadi antara lain karena kekurangan pengetahuan pengelolaan dan langkah-langkah pencegahannya dari petani sampai tingkat konsumen. ${ }^{5}$

Prevalensi penyakit cacing yang ditularkan melalui tanah di daerah tropik masih cukup tinggi. Di Indonesia, nematoda usus masih menjadi masalah kesehatan masyarakat adalah Ascaris lumbricoides, cacing tambang, dan Trichuris trichiura. Salah satu sumber penularannya adalah air dan lumpur yang digunakan dalam budidaya sayuran. ${ }^{5}$ Tanah, sayur-sayuran, dan air merupakan media transmisi yang pentin. ${ }^{6}$ Kebiasaan defekasi di tanah dan pemakaian tinja sebagai pupuk kebun (di berbagai daerah tertentu) penting dalam penyebaran infeksi. ${ }^{7}$

Kontaminasi (contamination) atau adanya agent menular pada permukaan tubuh, pada atau dalam pakaian, termasuk semua yang berkaitan dengan tempat tidur (beeding), mainan, alat-alat bedah atau baju operasi, maupun benda/zat mati termasuk air dan makanan. ${ }^{8}$ Semakin banyak telur ditemukan di sumber kontaminasi (tanah, debu, sayuran dan lain-lain), semakin tinggi derajat endemi di suatu daerah. ${ }^{7}$

Secara umum terdapat dua cara masuknya nematoda usus dalam menginfeksi tubuh manusia, yaitu melalui mulut dan kulit. Adanya telur-telur atau larva, dalam beberapa kasus ditemukan dari hasil pemeriksaan kasus infeksi. Telur-telur tersebut dapat masuk ke dalam tubuh manusia, diantaranya melalui tidak bersih dalam mencuci, sayuran yang tidak dimasak sedangkan dari larva nematoda usus dapat dimungkinkan melalui air yang terkontaminasi. Pada beberapa parasit, dijumpai salah satu cara yang penting dari penularan (transmissi) nematoda usus, yaitu penularan melalui fecal-oral melalui jari tangan yang tidak dicuci bersih. ${ }^{9}$ Penularan kepada hospes baru tergantung kepada tertelannya telur matang yang infektif atau larva, atau menembusnnya larva ke dalam kulit atau selaput lendir. Seringkali larva di dalam telur ikut tertelan dengan makanan. ${ }^{10}$

Yogyakarta terkenal dengan sebutan Kota Pendidikan, sehingga banyak didatangi oleh para pelajar/mahasiswa sebagai tujuan belajar. Oleh karena itu menjadi peluang bisnis bagi masyarakat, khususnya untuk menyediakan konsumsi/ 
makan untuk kebutuhan mereka. Salah satunya adalah kecamatan Umbulharjo yang berada di tengah-tengah kota yogyakarta. Dikelilingi oleh beberapa perguruan tinggi seperti Universitas Ahmad Dahlan, Universitas Teknologi Yogyakarta, Universitas Sarjanawiyata Tamansiswa dan beberapa perguruan tinggi lain. Sehingga dengan adanya banyak perguruan tinggi tersebut didapatkan banyak pula para pedagang makanan khususnya adalah pecel lele.

Pecel lele merupakan makanan yang sudah tidak asing lagi bagi kalangan mahasiswa, karena mudah didapat dan harganyapun tidak mahal. Hampir di sepanjang jalan terdapat penjual pecel lele. Dimana pecel lele berisi nasi, dengan lauk lele goreng dan diberikan sambal dan lalapan sebagai tambahannya. Dimana lalapan salah satunya adalah kubis.

Dari hasil observasi pendahuluan ternyata didapatkan ada 26 penjual pecel lele yang terdapat di Kecamatan Umbulharjo Kota Yogyakarta. Dan 3 dari penjual pecel lele tersebut ternyata perilaku dalam mencuci lalapan kubisnya tidak dibuka perhelainya dan mencucinya dimasukkan ke dalam ember saja.

Berdasarkan hal tersebut, maka penulis tertarik untuk melakukan penelitian dengan judul hubungan perilaku mencuci dengan kontaminasi telur nematoda usus yang terdapat pada sayuran kubis (Brassica oleracea) yang digunakan sebagai sajian lalapan pada pedagang pecel lele di kecamatan Umbulharjo Kota Yogyakarta.

\section{METODE PENELITIAN}

Jenis penelitian ini adalah observasional analitik dengan rancangan penelitian cross sectional. Populasi penelitian ini adalah pedagang pecel lele yang berada di Kelurahan Warungboto Kota Yogyakarta yaitu sebanyak 26 pedagang pecel lele, dan menggunakan teknik pengambilan sampel yaitu totality sampling.

\section{HASIL PENELITIAN DAN PEMBAHASAN}

\section{A. HASIL PENELITIAN}

\section{1) Deskripsi Lokasi Penelitian}

Kelurahan Warungboto merupakan bagian dari wilayah Kecamatan Umbulharjo, Yogyakarta. Wilayah KelurahanWarungboto terbagi dalam $9 \mathrm{Ru}$ kun Warga (RW) dan 38 Rukun Tetangga (RT). Adapun batas-batas wilayah Kelurahan Warungboto adalah sebagai berikut :

a. Sebelah utara berbatasan dengan Kelurahan Muja Muju,

b. Sebelah selatan berbatasan dengan Kelurahan Pandeyan,

c. Sebelah barat berbatasan dengan Kelurahan Tahunan, dan

d. Sebelah timur berbatasan dengan Kelurahan Rejowinangun Kecamatan

Kota Gede.

Wilayah Kelurahan Warungboto Kecamatan Umbulharjo, Yogyakarta merupakan area pendidikan, dimana dikelilingi oleh beberapa perguruan tinggi seperti Universitas Ahmad Dahlan, Universitas Teknologi Yogyakarta, Universitas Sarjanawiyata Tamansiswa. Hal tersebut mengakibatkan di wilayah Kelurahan Warungboto banyak terdapat para pedagang makanan khususnya adalah pecel lele.

\section{2) Analisis Univariat}


a) Distribusi Frekuensi Responden Berdasarkan Perilaku Mencuci Sayuran Kubis

Tabel 1. Distribusi Responden Berdasarkan Perilaku Mencuci Sayuran Kubis (Brassica oleracea) Pecel Lele Kelurahan Warungboto Kota Yogyakarta Tahun 2011

\begin{tabular}{|c|c|c|}
\hline Perilaku Mencuci Sayur & Jumlah & Persentase (\%) \\
\hline Tidak Baik & 16 & 61,5 \\
\hline Baik & 10 & 38,5 \\
\hline
\end{tabular}

Pada tabel 1, terlihat bahwa dari 26 sampel uji yang diteliti, terdapat 16 responden $(61,5 \%)$ memiliki perilaku mencuci sayuran kubis tidak baik, sedangkan yang memiliki perilaku mencuci sayuran yang baik sebanyak 10 responden (38,5\%).

b) Distribusi Frekuensi Kontaminasi Telur Cacing

Tabel 2. Distribusi Kontaminasi Telur Cacing Nematoda Usus pada Sayuran Kubis (Brassica oleracea) Pecel Lele Kelurahan Warungboto Kota Yogyakarta Tahun 2011

\begin{tabular}{|c|c|c|}
\hline Kontaminasi Telur Cacing & Jumlah & Persentase (\%) \\
\hline Kontaminasi & 6 & 23,1 \\
\hline Tidak Kontaminasi & 20 & 76,9 \\
\hline
\end{tabular}

Pada tabel 2, terlihat bahwa dari 26 sampel uji yang diteliti, terdapat 6 sampel sayuran kubis $(23,1 \%)$ terkontaminasi telur nematoda usus, sedangkan yang tidak terkontaminasi telur nematoda usus sebesar 20 sampel sayuran kubis $(76,9 \%)$.

\section{(1) Hasil Pemeriksaan Spesies Telur Nematoda Usus}

Spesies telur nematoda usus yang ditemukan dari hasil pemeriksaan preparat sedimen yang diperiksa meliputi spesies telur Ascaris lumbricoides, Trichuris trichiura, sedangkan telur nematoda usus spesies cacing tambang dan Enterobius vermicularis tidak ditemukan. Hasil pemeriksaan spesies telur nematoda usus pada sayurankubis dapat dilihat pada tabel berikut :

\begin{tabular}{|c|c|c|c|c|c|}
\hline \multicolumn{6}{|c|}{$\begin{array}{l}\text { Tabel 3. Hasil Pemeriksaan Spesies Telur Nematoda Usus Pada Sa- } \\
\text { yuran Kubis (Brassica oleracea) Pecel Lele Kelurahan Wa- } \\
\text { rungboto Kota Yogyakarta Tahun } 2011\end{array}$} \\
\hline \multirow[b]{2}{*}{ No } & \multirow[b]{2}{*}{$\begin{array}{l}\text { Contoh } \\
\text { uji }\end{array}$} & \multicolumn{4}{|c|}{ Spesies Telur Nematoda Usus } \\
\hline & & $\begin{array}{l}\text { Ascaris } \\
\text { lumbri- } \\
\text { coides }\end{array}$ & $\begin{array}{c}\text { Cacing } \\
\text { tambang }\end{array}$ & $\begin{array}{l}\text { Trichuris } \\
\text { trichiura }\end{array}$ & $\begin{array}{c}\text { Enterobius } \\
\text { vermicu- } \\
\text { laris }\end{array}$ \\
\hline 1. & $\mathrm{KPC}_{1}$ & - & - & - & - \\
\hline 2. & $\mathrm{KPC}_{2}$ & - & - & - & - \\
\hline 3. & $\mathrm{KPC}_{3}$ & + & - & - & - \\
\hline 4. & $\mathrm{KPC}_{4}$ & - & - & - & - \\
\hline 5. & $\mathrm{KPC}_{5}$ & - & - & - & - \\
\hline 6. & $\mathrm{KPC}_{6}$ & - & - & - & - \\
\hline
\end{tabular}




\begin{tabular}{|c|l|c|c|c|c|}
\hline 7. & $\mathrm{KPC}_{7}$ & - & - & - & - \\
\hline 8. & $\mathrm{KPC}_{8}$ & - & - & - & - \\
\hline 9. & $\mathrm{KPC}_{9}$ & + & - & - & - \\
\hline 10. & $\mathrm{KPC}_{10}$ & + & - & - & - \\
\hline 11. & $\mathrm{KPC}_{11}$ & - & - & - & - \\
\hline 12. & $\mathrm{KPC}_{12}$ & - & - & - & - \\
\hline 13. & $\mathrm{KPC}_{13}$ & - & - & - & - \\
\hline 14. & $\mathrm{KPC}_{14}$ & - & - & - & - \\
\hline 15. & $\mathrm{KPC}_{15}$ & - & - & - & - \\
\hline 16. & $\mathrm{KPC}_{16}$ & - & - & - & - \\
\hline 17. & $\mathrm{KPC}_{17}$ & - & + & - & - \\
\hline 18. & $\mathrm{KPC}_{18}$ & + & - & - & - \\
\hline 19. & $\mathrm{KPC}_{19}$ & + & - & - & - \\
\hline 20. & $\mathrm{KPC}_{20}$ & - & - & - & - \\
\hline 21. & $\mathrm{KPC}_{21}$ & - & - & - & - \\
\hline 22. & $\mathrm{KPC}_{22}$ & - & - & - & - \\
\hline 23. & $\mathrm{KPC}_{23}$ & - & - & - & - \\
\hline 24. & $\mathrm{KPC}_{24}$ & - & - & - & - \\
\hline 25. & $\mathrm{KPC}_{25}$ & - & - & - & - \\
\hline 26. & $\mathrm{KPC}_{26}$ & - & - & - & - \\
\hline
\end{tabular}

Sumber : Data Primer

Hasil pemeriksaan spesies telur nematoda usus pada sayuran kubis, diketahui terdapat beberapa spesies telur nematoda usus. Spesies telur nematoda usus yang paling banyak diketemukan adalah telur Ascaris lumbricoides yaitu sebanyak 5 contoh uji sayuran kubis yang diperiksa dan spesies telur Trichuris trichiura yaitu sebanyak 1 contoh uji sayuran kubis yang diperiksa. Dari 6 contoh uji (sampel) sayuran kubis yang diketahui spesies telur nematoda ususnya merupakan kontaminasi tunggal yaitu hanya menemukan satu spesies dalam tiap sampel.

Persentase spesies telur nematoda usus yang ditemukan pada sayuran kubis yang diperiksa dapat ditunjukkan pada grafik berikut :

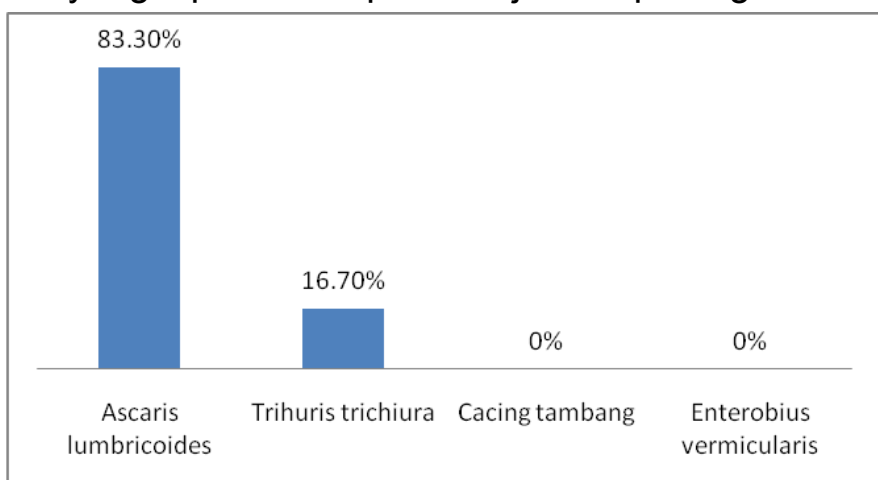

Gambar 16. Grafik Persentase Spesies Telur Nematoda Usus 
(2) Hasil Pemeriksaan Bentuk Infektif Telur Nematoda Usus

Bentuk infektif dari spesies telur yang diketahui memberikan hasil pemeriksaan positif kontaminasi telur nematoda usus pada sayuran kubis yang diperiksa, ditemukan sebanyak 2 buah telur bentuk infektif dari telur nematoda usus spesies Ascaris lumbricoides pada satu contoh uji (contoh uji K7). Data hasil pemeriksaan ditunjukkan pada tabel berikut :

Tabel 4. Hasil Pemeriksaan Bentuk Infektif Spesies Telur Nematoda Usus Pada Sayuran Kubis (Brassica oleracea) Pecel Lele Kelurahan Warungboto Kota Yogyakarta Tahun 2011

\begin{tabular}{|c|c|c|c|c|c|c|c|c|c|}
\hline \multirow{3}{*}{ No } & \multirow{3}{*}{$\begin{array}{l}\text { Contoh } \\
\text { uji }\end{array}$} & \multicolumn{8}{|c|}{ Spesies Telur Nematoda Usus } \\
\hline & & \multicolumn{2}{|c|}{$\begin{array}{l}\text { Ascaris lumbri- } \\
\text { coides }\end{array}$} & \multicolumn{2}{|c|}{$\begin{array}{l}\text { Cacing tam- } \\
\text { bang }\end{array}$} & \multicolumn{2}{|c|}{$\begin{array}{c}\text { Trichuris trichi- } \\
\text { ura }\end{array}$} & \multicolumn{2}{|c|}{$\begin{array}{c}\text { Enterobius ver- } \\
\text { micularis }\end{array}$} \\
\hline & & Infektif & $\begin{array}{l}\text { Non- } \\
\text { Infektif }\end{array}$ & Infektif & $\begin{array}{l}\text { Non- } \\
\text { Infektif }\end{array}$ & Infektif & $\begin{array}{l}\text { Non- } \\
\text { Infektif }\end{array}$ & Infektif & $\begin{array}{l}\text { Non- } \\
\text { Infektif }\end{array}$ \\
\hline 1. & $\mathrm{KPC}_{1}$ & - & - & - & - & - & - & - & - \\
\hline 2. & $\mathrm{KPC}_{2}$ & - & - & - & - & - & - & - & - \\
\hline 3. & $\mathrm{KPC}_{3}$ & - & + & - & - & - & - & - & - \\
\hline 4. & $\mathrm{KPC}_{4}$ & - & - & - & - & - & - & - & - \\
\hline 5. & $\mathrm{KPC}_{5}$ & - & - & - & - & - & - & - & - \\
\hline 6. & $\mathrm{KPC}_{6}$ & - & - & - & - & - & - & - & - \\
\hline 7. & $\mathrm{KPC}_{7}$ & - & - & - & - & - & - & - & - \\
\hline 8. & $\mathrm{KPC}_{8}$ & - & - & - & - & - & - & - & - \\
\hline 9. & $\mathrm{KPC}_{9}$ & - & + & - & - & - & - & - & - \\
\hline 10. & $\mathrm{KPC}_{10}$ & - & + & - & - & - & - & - & - \\
\hline 11. & $\mathrm{KPC}_{11}$ & - & - & - & - & - & - & - & - \\
\hline 12. & $\mathrm{KPC}_{12}$ & - & - & - & - & - & - & - & - \\
\hline 13. & $\mathrm{KPC}_{13}$ & - & - & - & - & - & - & - & - \\
\hline 14. & $\mathrm{KPC}_{14}$ & - & - & - & - & - & - & - & - \\
\hline 15. & $\mathrm{KPC}_{15}$ & - & - & - & - & - & - & - & - \\
\hline 16. & $\mathrm{KPC}_{16}$ & - & - & - & - & - & - & - & - \\
\hline 17. & $\mathrm{KPC}_{17}$ & - & - & - & - & - & + & - & - \\
\hline 18. & $\mathrm{KPC}_{18}$ & - & + & - & - & - & - & - & - \\
\hline 19. & $\mathrm{KPC}_{19}$ & - & + & - & - & - & - & - & - \\
\hline 20. & $\mathrm{KPC}_{20}$ & - & - & - & - & - & - & - & - \\
\hline 21. & $\mathrm{KPC}_{21}$ & - & - & - & - & - & - & - & - \\
\hline 22. & $\mathrm{KPC}_{22}$ & - & - & - & - & - & - & - & - \\
\hline 23. & $\mathrm{KPC}_{23}$ & - & - & - & - & - & - & - & - \\
\hline 24. & $\mathrm{KPC}_{24}$ & - & - & - & - & - & - & - & - \\
\hline 25. & $\mathrm{KPC}_{25}$ & - & - & - & - & - & - & - & - \\
\hline 26. & $\mathrm{KPC}_{26}$ & - & - & - & - & - & - & - & - \\
\hline
\end{tabular}

Tabel tersebut menunjukkan bahwa walaupun memberikan hasil pemeriksaan positif kontaminasi telur nematoda usus seperti spesies 
telur Ascaris lumbricoides, cacing tambang dan spesies telur Trichuris trichiura akan tetapi tidak ditemukan adanya bentuk infektif dari spesies telur nematoda usus tersebut.

\section{3) Analisis Bivariat}

Hubungan perilaku mencuci sayuran kubis dengan kontaminasi telur nematoda usus

Hasil analisis bivariat antara perilaku mencuci sayuran kubis dengan kontaminasi telur nematoda usus ditunjukkan pada tabel 5 , berikut :

\begin{tabular}{|c|c|c|c|c|c|c|c|c|c|}
\hline \multirow[t]{3}{*}{ No } & \multirow{3}{*}{$\begin{array}{l}\text { Perilaku } \\
\text { Mencuci } \\
\text { Sayuran }\end{array}$} & \multicolumn{4}{|c|}{$\begin{array}{c}\text { Kontaminasi Telur } \\
\text { Nematoda Usus } \\
\end{array}$} & \multirow{2}{*}{\multicolumn{2}{|c|}{ Total }} & \multirow{2}{*}{$\begin{array}{c}\mathrm{RP} \\
(95 \% \mathrm{Cl})\end{array}$} & \multirow{2}{*}{ Sig } \\
\hline & & \multicolumn{2}{|c|}{$\begin{array}{l}\text { Kontami- } \\
\text { nasi }\end{array}$} & \multicolumn{2}{|c|}{$\begin{array}{l}\text { Tidak Kon- } \\
\text { taminasi }\end{array}$} & & & & \\
\hline & & $\mathrm{n}$ & $\%$ & $\mathrm{n}$ & $\%$ & $n$ & $\%$ & 3,125 & 0,35 \\
\hline 1. & $\begin{array}{l}\text { Tidak } \\
\text { Baik }\end{array}$ & 5 & 19,2 & 11 & 42,3 & 16 & 61,5 & $\begin{array}{l}(0,424- \\
23,007)\end{array}$ & \\
\hline 2. & Baik & 1 & 0,4 & 9 & 34,6 & 10 & 38,5 & & \\
\hline & Total & 6 & 23,1 & 20 & 76,9 & 26 & 100 & & \\
\hline
\end{tabular}

Tabel 5, menunjukkan bahwa 16 responden $(61,5 \%)$ yang memiliki perilaku mencuci sayuran tidak baik, terdapat $5(19,2 \%)$ sampel uji yang terkontaminasi telur nematoda usus dan 11 (42,3\%) sampel uji tidak terkontaminasi nematoda usus. Sedangkan yang memiliki perilaku mencuci sayuran yang baik sebanyak 10 responden $(38,5 \%)$, terdapat $1(0,4 \%)$ sampel uji terkontaminasi telur nematoda usus dan 9 sampel uji $(34,6 \%)$ sampel uji tidak terkontaminasi nematoda usus.

Hasil uji statistik dengan $\alpha=0,05$ didapatkan nilai $\mathrm{RP}=3,125(95 \% \mathrm{Cl}$ : 0,424-23,007), yang berarti bahwa responden yang memiliki perilaku mencuci sayuran yang tidak baik akan meningkatkan kemungkinan risiko adanya kontaminasi telur nematoda usus sebesar 3,125 kali lebih besar dibandingkan dengan responden yang memiliki perilaku mencuci sayuran yang baik, namun secara statistic tidak bermakna $(p=0,35)$.

\section{B. PEMBAHASAN}

\section{1) Perilaku Mencuci Sayuran Kubis Dengan Kontaminasi Telur Nematoda Usus}

Berdasarkan hasil penelitian yang dilakukan pada 26 sampel uji, diperoleh data bahwa respoden yang memiliki perilaku mencuci sayuran kubis yang tidak baik terdapat 16 responden (61,5\%), sedangkan yang memiliki perilaku mencuci sayuran dengan baik terdapat 10 responden $(38,5 \%)$. Hasil penelitian ini menunjukkan bakwa perilaku mencuci sayuran kubis di warung pecel lele Kelurahan Warungboto Kota Yogyakarta masih cukup tinggi.

Perilaku pedagang dalam mencuci sayuran kubis yang kurang baik sehingga terdapat adanya kontaminasi telur cacing nematoda usus dapat disebabkan oleh oleh kurangnya kesadaran pedagang dalam menjaga kebersihan makanan yang akan disajikan kepada konsumen. Hal ini dapat terlihat dari kubis yang disajikan hanya dipotong secara utuh dan tidak dibuka tiap helainya. Jika terdapat kontaminasi telur nematoda usus pada 
lalapan kubis maka hal ini dapat menyebabkan telur nematoda usus tersebut dapat tertelan oleh para konsumen sehingga dapat terinfeksi telur cacing. Selain itu, para pedagang pecel lele ada juga yang hanya mencuci bagian luar kubisnya saja sehingga hal ini tidak akan dapat mengurangi tingkat kontaminasi telur nematoda usus pada lalapan pecel lele.

Perilaku mencuci sayuran kubis yang tidak baik oleh para pedagang masih cukup tinggi yaitu sebesar $(61,5 \%)$. Masih banyak para pedagang yang tidak mencuci sayuran kubis untuk disajikan kepada konsumen sehingga jika terdapat kotoran atau telur cacing pada kubis dapat termakan oleh konsumen. Selain itu juga perilaku pedagang yang tidak menggunakan air mengalir untuk mencuci sayuran kubis seperti hanya menggunakan baskom dengan air yang tidak mengalir dan tidak di ganti-ganti dalam proses mencuci sayuran sehingga masih perbeluang besar apabila terdapat telur cacing maka masih tetap menempel pada sayuran kubis. Hal ini dapat terlihat dari kubis yang disajikan hanya dipotong secara utuh dan tidak dibuka tiap helainya. Jika terdapat kontaminasi telur nematoda usus pada lalapan kubis maka hal ini dapat menyebabkan telur nematoda usus tersebut dapat tertelan oleh para konsumen sehingga dapat terinfeksi telur cacing. Selain itu, para pedagang pecel lele ada juga yang hanya mencuci bagian luar kubisnya saja sehingga hal ini tidak akan dapat mengurangi tingkat kontaminasi telur nematoda usus pada lalapan pecel lele.

\section{2) Spesies Telur Nematoda Usus Yang Terdapat Pada Sayuran Kubis}

Hasil pemeriksaan sayuran kubis yang telah dilakukan dapat diketahui bahwa spesies telur yang banyak ditemukan adalah spesies telur Ascaris lumbricoides sebesar $(83,30 \%)$, sedangkan spesies telur Trichuris trichiura sebesar (16,7\%), namun spesies cacing tambang dan Enterobius vermicularis tidak ditemukan. Meskipun diperoleh hasil pemeriksaan positif, seperti Ascaris lumbricoides dan Trichuris trichiura, akan tetapi semua spesies telur nematoda yang ditemukan bentuk non infektif.

Dominasi telur Ascaris lumbricoides pada penelitian ini lebih disebabkan oleh sifat dari telur Ascaris lumbricoides yang di dalam tanah tetap hidup pada suhu beku yang biasa terdapat pada musim dingin. Telur tahan terhadap desinfektans kimiawi dan terhadap rendaman sementara di dalam berbagai bahan kimia yang keras. Telur dapat hidup berbulan-bulan di dalam air selokan dan tinja. Tidak ditemukannya telur Enterobius vermicularis kemungkinan dikarenakan oleh sifat dari telur cacing kremi yang penularannya lebih cenderung bersifat retrofeksi, dan kontaminasi pada makanan serta inhalasi telur lewat debu. Daerah penyebarannya yang meliputi kamar tidur, kafetaria, tempat duduk, kakus, kasur dan tilam. Pertumbuhan dan perkembangan telur cacing kremi tidak melalui media tanah secara langsung. ${ }^{10}$

Tidak ditemukannya telur cacing tambang pada penelitian ini dapat disebabkan karena beberapa faktor, diantaranya yaitu jenis tanah. Telur cacing tambang dapat tumbuh optimum pada lingkungan yang mengandung pasir karena pasir memiliki berat jenis yang lebih besar dari pada air sehingga telur-telur akan terlindung dari sinar matahari. Suhu juga merupakan faktor yang mempengaruhi pertumbuhan telur cacing tambang. Suhu optimum pertumbuhan cacing tambang yaitu $45^{\circ} \mathrm{C}$, namun suhu daerah perkebunan sayuran kubis relatif lebih dingin berkisar antara $20^{\circ} \mathrm{C}$ $30^{\circ} \mathrm{C}$ sehingga tidak baik untuk pertumbuhan telur cacing tambang. ${ }^{11}$ 
3) Hubungan Antara Perilaku Mencuci Sayuran Kubis Dengan Kontaminasi Telur Nematoda Usus

Berdasarkan hasil analisis bivariat dengan menggunakan uji chi-square $\left(\mathrm{X}^{2}\right)$ hubungan antara perilaku mencuci sayuran kubis dengan kontaminasi telur nematoda usus pada tabel 7 , menunjukkan bahwa dari 16 responden $(61,5 \%)$ yang memilki perilaku mencuci sayuran kubis tidak baik, terdapat 5 sampel uji $(19,2 \%)$ yang terkontaminasi telur nematoda usus dan 11 sampel uji $(42,3 \%)$ yang tidak terkontaminasi telur nematoda usus, sedangkan dari 10 responden $(38,5 \%)$ yang memilki perilaku mencuci sayuran kubis yang baik, terdapat 1 sampel uji $(0,4 \%)$ yang terkontaminasi telur nematoda usus dan 9 sampel uji $(76,9 \%)$ tidak terkontaminasi telur nematoda usus.

Diperoleh nilai $p=0,35$ dengan $\alpha=0,05$ berarti dapat dinyatakan bahwa tidak ada hubungan antara perilaku mencuci sayuran dengan kontaminasi telur nematoda usus. Nilai $R P=3,125$ (95\% Cl: 0,424-23,007), yang berarti bahwa responden yang memilki perilaku mencuci sayuran tidak baik bukan merupakan risiko terhadap kontaminasi telur nematoda usus jika dibandingkan responden yang memiliki perilaku mencuci sayuran baik, namun secara statistik dan biologis tidak bermakna.

Hal ini dapat disebabkan oleh pencucian sayuran yang tidak mengunakan air bersih seperti air PDAM dan air sumur yang kualitas airnya buruk. Selain itu dapat juga disebabkan oleh proses pencucian sayuran kubis yang tidak menggunakan air yang mengalir. Hygienitas para pedagang warung makan lesehan terutama hubunganya dengan kebersihan makanan yang disajikan memiliki andil terhadap kualitas makanan yang disajikan, baik kebersihan, kesehatan, maupun nilai gizi. ${ }^{12}$

Beberapa faktor yang berpengaruh terhadap kebersihan dalam pengolahan dan pemanfaatan sayuran yang dikonsumsi oleh manusia, seperti cara mencuci sayuran dan teknik mencuci merupakan hal yang perlu diperhatikan. Mencuci dengan teknik merendam di dalam wadah seperti baskom dan panci kotoran yang tadinya terlepas bisa menempel kembali di sayuran. Pencucian sayur dengan air yang mengalir akan membuat sayur menjadi bersih, karena air yang datang ke sayur dalam kondisi bersih akan membawa kotoran, debu, kuman, parasit dan lain sebagainya ke air buangan yang telah terlepas dan terbawa air sehingga tidak akan bisa mencari sayur-sayuran yang akan disajikan. ${ }^{2}$

Berdasarkan wawancara yang dilakukan dengan supir truk yang membawa sayuran kubis untuk didistribusikan ke berbagai pasar yang ada di Yogyakarta, kontaminasi sayuran oleh telur nematoda usus diduga berasal dari air penyiram yang digunakan oleh para petani perkebunan sayur untuk menyiram sayuran kubis, karena air penyiram berasal dari kolam yang juga dipergunakan untuk buang air besar oleh masyarakat sekitar. Setelah sayuran dipanen, keesokan harinya kemudian diangkut menuju kota/pasar untuk dijual, supaya tidak layu, sayuran disiram dengan air selokan ataupun air sungai yang berada ditempat terdekat dengan perkebunan kubis tersebut. Air selokan atau air sungai yang digunakan dikhawatirkan mengandung telur nematoda usus sehingga dapat mengkontaminasi sayuran kubis pada saat proses penyiraman dan menempel pada sayuran kubis. 
Masyarakat di sekitar perkebunan masih banyak yang melakukan aktivitas buang air besar di jamban yang berada di kolam-kolam yang terdapat dekat dengan area perkebunan sayuran kubis. Kolam-kolam yang digunakan sebagai wadah penampungan feaces yang berasal dari masyarakat sekitar tersebut terdapat saluran air yang mengalir menuju parit atau sungai. Oleh karena itu, jika terdapat orang yang terinfeksi cacingan maka telur cacing yang berada pada kolam tersebut dapat mengalir menuju sungai sehingga dapat mencemari air sungai. Apabila air sungai tersebut digunakan untuk mencuci dan menyiram sayuran kubis setelah dipanen dikhawatirkan telur nematoda usus dapat menempel pada sayuran kubis.

Penelitian yang dilakukan oleh Kodijat pada tahun 1988, menunjukkan bahwa sumber kontaminasi juga berasal dari air dan lumpur yang berasal dari PLTA Bandung, yang sepanjang alirannya dipakai untuk menyiram, mencuci dan memupuk tanaman/sayuran. Hasil penelitian tersebut menunjukkan bahwa air $(36,8 \%)$ dan lumpur $(21,0 \%)$ telah tercemar dengan telur $A$. lumbricoides, $T$. trichiura dan cacing tambang dan juga ditemukan adanya larva rhabditiform dan larva filariform. Hal yang sama juga ditunjukkan oleh penelitian yang dilakukan oleh Fauzan pada tahun 1992, bahwa sumber pencemaran telur nematoda usus yakni melalui penyiraman sayuran.

\section{SIMPULAN DAN SARAN}

\section{A. SIMPULAN}

1) Terdapat 16 responden $(61,5 \%)$ memiliki perilaku mencuci sayuran kubis yang tidak baik, sedangkan yang memiliki perilaku mencuci sayuran yang baik sebanyak 10 responden (38,5\%) pada warung pecel lele di Kelurahan Warungboto Kota Yogyakarta Tahun 2011.

2) Spesies telur nematoda usus yang mengkontaminasi sayuran kubis (Brassica oleracea) yang digunakan sebagai sayur lalapan mentah pada warung makan lesehan di Kelurahan Warungboto Kota Yogyakarta, meliputi spesies telur Ascaris lumbricoides (83,3\%), Trichuris trichiura (16,7\%), namun spesies Cacing tambang dan Enterobius vermicularis tidak ditemukan.

3) Tidak ada hubungan antara perilaku mencuci sayuran dengan kontaminasi telur cacing pada sayuran kubis di warung pecel lele Kelurahan Warungboto Kota Yogyakarta 2011. Dengan hasil uji statistik $\alpha=0,05$ didapatkan nilai $R P=3,125$ (95\% Cl: 0,424-23,007), dan $\mathrm{p}=0,35$

\section{B. SARAN}

1) Kepada Dinas Kesehatan Kota Yogyakarta; perlu dilakukan penyuluhan kepada pedagang warung makan lesehan mengenai kontaminasi telur nematoda usus pada sayuran kubis (Brassica oleracea) yang digunakan sebagai sayur lalapan mentah pada warung pecel lele di Kelurahan Warungboto Kota Yogyakarta.

2) Fakultas Kesehatan Masyarakat UAD; Perlu dilakukan penelitian lebih lanjut mengenai pencemaran nematoda usus dengan metode penelitian deskriptif kuantitatif analitik, seperti mengetahui faktor-faktor perilaku dalam pemanfaatan dan pengolahan sayuran yang dikonsumsi secara mentah. 


\section{DAFTAR PUSTAKA}

1. Yuniastuti, Endang, Dewi, Widyatmani Sih, 2007, Program Pengembangan Budaya Kewirausahaan di Perguruan Tinggi : http://lppm.uns.ac.id, diambil pada tanggal 7 Juli 2010, Yogyakarta.

2. Anonim, 2010a, Manfaat Lalapan Untuk Kesehatan : http://www.prlog.org, diambil pada tanggal 7 Juli 2010, Yogyakarta.

3. Pracaya, 2005, Kol alias Kubis, Penebar Swadaya, Jakarta.

4. Rukmana, R., 1994, Seri Budi Daya : Kubis, Penerbit Kanisius, Yogyakarta.

5. Kodijat, S., 1988, "Salah Satu Kemungkinan Penyebab Kontaminasi Sayuran Mentah dengan Cacing-Cacing yang Ditularkan Melalui Tanah", Abstrak Makalah Dalam Prosiding Seminar Parasitologi Nasional V, Perkumpulan Pemberantasan Penyakit Parasit Indonesia, Jakarta.

6. Depary, A.A., 1999, "Helminthiasis Intestinal Di Kalangan Mahasiswa-Baru Suatu Akademi Keperawatan Di Medan", Majalah Kedokteran Nusantara, Medical Journal Of The University Of North Sumatra, Vol. XXIX No. 2 Juni 1999, Hal : 19 - 21, Fakultas Kedokteran Universitas Sumatera Utara, Medan.

7. Gandahusada, S., H, Herry D. Ilahude, Wita Pribadi, 2003, Parasitologi Kedokteran, Gaya Baru, Jakarta.

8. Noor, N. N., 2006, Pengantar Epidemiologi Penyakit Menular, Rineka Cipta, Jakarta.

9. Gillespie, H. S., Richard D. Pearson, 2001, Principles and Practice of Clinical Parasitology, John Wiley \& Sons Ltd, USA.

10. Brown, W., H., 1983, Dasar Parasitologi Klinis, PT. Gramedia , Jakarta.

11. Sandjaja, B., 2007, Helmintologi Kedokteran, Prestasi Pustaka, Jakarta : Hal.38, 78-79, 124

12. Zulkarnain, A., 2010, Pengolahan dan Pemanfaatan Sayuran untuk Keluarga: http://www.mediagizi.org, diambil pada tanggal 3 Oktober 2010, Yogyakarta. 